\title{
Sacubitril/Valsartan and implantable cardioverter- -defibrillators: evolving therapeutic strategies. A case report
}

\author{
Claudia Morabitoa, Marianna Gigliotti De Fazioa , Michele Scaranob, \\ Vito Maurizio Paratob ${ }^{b}$ Giuseppe Dattiloa, Matteo Casale ${ }^{c}$ \\ a Department of Clinical and Experimental Medicine, University of Messina, Italy \\ ' Operative Unit of ICCU and Cardiology, Hospital "Madonna del Soccorso", ASUR Marche - Area Vasta 5, San Benedetto del \\ Tronto, Italy \\ "Operative Unit of ICCU and Cardiology, Hospital "S. Maria della Misericordia", ASUR Marche - Area Vasta 1, Urbino, Italy
}

\section{ARTICLE INFO}

\section{Article history:}

Submitted: 8. 4. 2020

Accepted: 14. 4. 2020

Available online: 22. 10. 2020

\section{Kličcová slova:}

ARNI

ICD

Sacubitril/valsartan

Srdeční implantabilní elektronické

prístroje

Srdeční selhání

Keywords:

ARNI

Cardiac implantable electronic

devices

Heart failure

ICD

Sacubitril/Valsartan

\section{SOUHRN}

Srdeční selhání - jako jeden z nejčastějších důvodů pro hospitalizaci - představuje významný problém veřejného zdraví. Jeho prognóza je nepříznivá a optimální péče o pacienty s tímto onemocněním je dlouhodobě velmi náročná. Tato kazuistika popisuje prípad 67letého muže s chronickým srdečním selháním se sníženou ejekční frakcí (heart failure with reduced ejection fraction, HFrEF), u něhož i přes optimální medikamentózní léčbu přetrvávaly symptomy a který odmítal zavedení implantabilního kardioverteru-defibrilátoru (ICD) jako prevenci náhlé srdeční smrti. Zahájili jsme podávání kombinace sacubitril/valsartan a po třech měsících léčby jsme zaznamenali významné zmírnění symptomů se sniženou zátěží arytmiemi, a po šesti měsících dokonce i zlepšení echokardiografických parametrů, což umožnilo zrušit indikaci ICD.

(c) 2020, ČKS.

\section{ABSTRACT}

Heart failure is a major public health concern, being one of the most common reasons for hospitalization. Its prognosis is poor and the optimal management to date represents a continuous challenge. This case report describes a 67-year-old man with chronic heart failure with reduced ejection fraction (HFrEF), remaining symptomatic despite optimal medical therapy and refusing an implantable cardioverter-defibrillator (ICD) as a prevention for sudden cardiac death. We introduced Sacubitril/Nalsartan and after 3 months of treatment we observed a significant improvement in symptoms with reduction of arrhythmic burden and, after six months even of echocardiographic parameters, leading to withdraw the indication to the ICD.

\section{Introduction}

Heart failure (HF) is a complex condition due to impaired ventricular contractility and/or relaxation. ${ }^{1}$ It is a major public health concern, being an epidemic disease and the most common reason for hospitalization among adults, with consequent considerable economic costs. ${ }^{1,2}$ Some authors in fact forecast an increase of the patients affected due to the population ageing, to the improvements of HF therapy and to the evolution of invasive treatment of coronary artery disease (the most frequent cause of HF). ${ }^{3}$ The prognosis is poor because of symptoms, functional limitations and reduced quality of life. ${ }^{4}$ Readmissions are common and mortality is high, affecting about $50 \%$ of patients within 5 years after diagnosis. ${ }^{1}$

In order to reduce risk of sudden death and all-cause mortality, implantation of a cardiac implantable cardioverter-defibrillator (ICD) is recommended as a secondary prevention (in patients surviving to cardiac arrest due to sustained ventricular arrhythmias) or as a primary prevention (in patients with symptomatic HF, LVEF $\leq 35 \%$ despite a period $\geq 3$ months of optimal medical therapy). ${ }^{5}$

Despite improvement of drug therapies and evolution of the devices, management of HF still today continues to be an important challenge. 


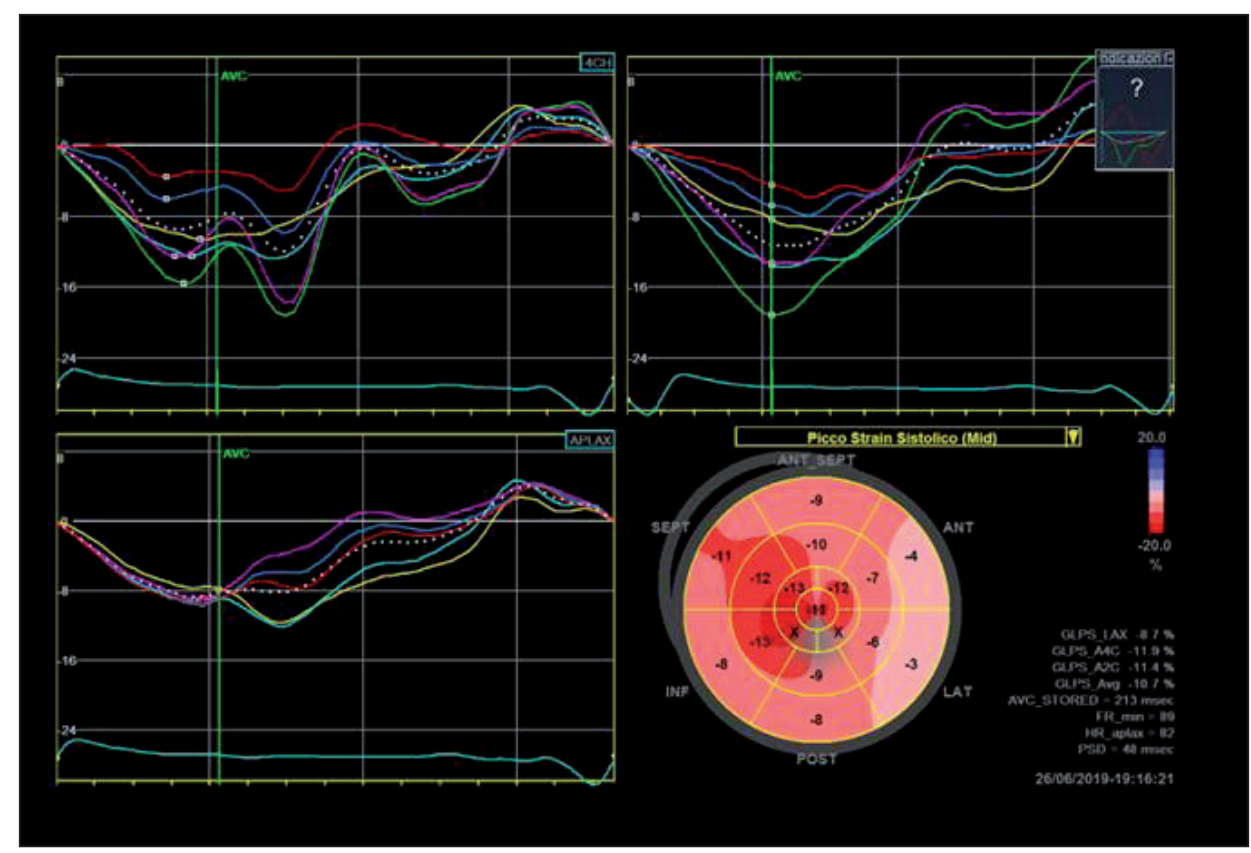

Fig. 1 - Global longitudinal strain before treatment with Sacubitril/Valsartan.

\section{Case report}

A 67-year-old man was referred to cardiac evaluation for evaluating his eligibility to ICD implantation. He had a history of chronic heart failure with reduced ejection fraction (HFrEF), chronic coronary syndrome (anterior myocardial infarction a year ago) and type 2 diabetes mellitus.

Physical examination showed BP $110 / 70 \mathrm{mmHg}$, mild basal rales, lower limbs oedema, functional NYHA class III. The ECG showed sinus rhythm 58 bpm, low voltages of QRS in the peripheral leads, left anterior fascicular block with QRS duration of $120 \mathrm{msec}$, some ventricular extrasystoles, nonspecific alterations of repolarization. An echocardiogram documented left ventricular ejection function (LVEF) of 30\%, with impairment of global longitudinal strain (GLS-11\%) (Fig. 1), a left ventricular end-diastolic diameter (LVEDD) of $61 \mathrm{~mm}$, moderate mitral regurgitation, pulmonary blood pressure of $50 \mathrm{mmHg}$. Blood test showed: BNP $2380 \mathrm{pg} / \mathrm{ml}, \mathrm{Na} 140$ $\mathrm{mEq} / \mathrm{dl}, \mathrm{K} 4,2 \mathrm{mEq} / \mathrm{dl}$, creatinine 1,2 mg/dl, $\mathrm{Hb} 10,8 \mathrm{gr} /$ dl. During a 6-min-walking test the subject walked 155 $\mathrm{m}$, showing poor functional status. The patient was already receiving optimal medical therapy according to HF guidelines: furosemide $25 \mathrm{mg} 2 \mathrm{cp}$ bid, Ramipril 5 $\mathrm{mg}$ bid, Bisoprolol $5 \mathrm{mg}$ (the maximum tolerated dose for this patient) and Kanrenone $100 \mathrm{mg}$. During the last hospitalization (six weeks before) amiodarone was added for the presence of ventricular extrasystoles, precociously interrupted after three weeks by the General Practitioner because of low blood pressure, severe bradycardia and QTc prolongation $>500 \mathrm{msec}$.

Despite the persistence of symptoms with an optimal medical therapy and a recent 24-hour ambulatory ECG showing high burden $(11 \%)$ of premature ventricular complexes (PVC) with several non-sustained polymor- phic ventricular tachycardias, he refused ICD implantation. We decided to introduce Sacubitril/Valsartan 49/51 $\mathrm{mg}$ bid and reduced furosemide to $25 \mathrm{mg}$ bid, suspending Kanrenone. Strict follow-up at one month was offered with the prescription of maintain a personal daily pressure diary.

At the one-month follow-up was observed by the pressure diary that after 2 weeks from starting ARNI therapy, BP values stabilized around $100 / 55 \mathrm{mmHg}$. Furosemide was completely suspended and the patient was motivated to continue using the drug despite mean systolic pressure at home was causing asthenia. We offered a 24-hour Holter ECG reevaluation at 2 months and subsequent cardiac evaluation.

Three months later we observed a significant improvement in symptoms, with a stabilization of blood pressure to $110 / 60 \mathrm{mmHg}$ after two weeks from the previous evaluation, and in laboratory parameters. In particular there was a reduction to NYHA class II, BNP was $856 \mathrm{pg} / \mathrm{ml}$ and renal function was stable. The subject walked longer distances in comparison with the baseline visit (215 m). After 6 months we observed even an improvement of echocardiographic parameters: LVEF was $40 \%$, GLS $-17 \%$ (Fig. 2), pulmonary BP $35 \mathrm{mmHg}$. In addition the most recent ambulatory ECG showed a reduction of PVC burden to $8 \%$ without episodes of ventricular arrhythmias. Finally, there was no more indication to the implantation of ICD, suggesting high efficacy of the treatment.

\section{Discussion}

This case report describes a patient with HFrEF, who remained symptomatic despite an optimal medical therapy (as defined by current guidelines) ${ }^{1}$ and refusing ICD implantation. Complicating the clinical scenario there were 


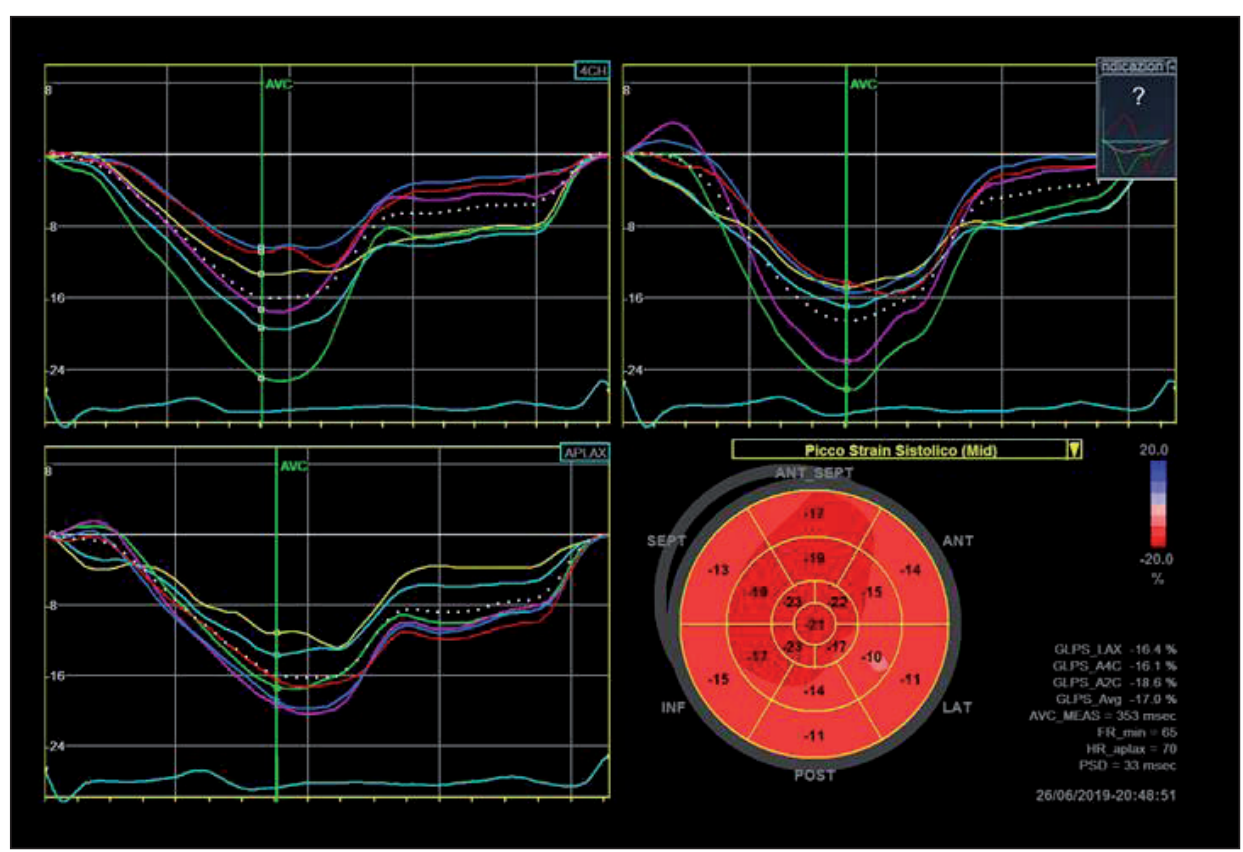

Fig. 2 - Global longitudinal strain after 6 months of treatment with Sacubitril/Valsartan.

a clear electrical instability (documented by ambulatory ECG recording with both high burden of PVC and non-sustained polymorphic VT) not manageable by amiodarone and an initial poor tolerance to ARNI therapy. After few weeks of treatment we observed a significant improvement of symptoms (with a reduction in NYHA class) and in functional ability (assessed by six-minute-walking test), even before the documentation of improvement of cardiac performance, as demonstrated by the increase in $E F$. One of the most interesting findings was an electrical stabilization (as showed by a second ambulatory ECG) before the improvement of EF and of GLS (a very sensitive echocardiographic tool). The direct consequence was withdrawing the indication to ICD implantation.

Currently ICD is recommended in patients with HFrEF after three months of optimal medical therapy to improve the survival. Optimal medical therapy involves neuro-hormonal antagonists (ACEIs/ARBs, MRAs and betablockers) because of a well-known mechanism related to HF progression. ${ }^{1}$

Sacubitril/Valsartan, a new class of drug with angiotensin-receptor and neprilysin inihibitor (ARNI), simultaneously inhibits the neurohormonal pathway of the reninangiotensin-aldosterone system (RAAS) and enhances the natriuretic peptides system. ${ }^{6}$ It induces a substantial improvement in symptoms and consequently in functional capacities, resulting in a reduction in NYHA class. ${ }^{7}$

Six-minute-walking test is a simple tool in HF patients assessing the effectiveness of treatment and adding a prognostic value in correlation with quality of life. ${ }^{8,9} \mathrm{An}$ increase in walking distance $>30$ to $50 \mathrm{~m}$ is considered to be associated with a relevant improvement in NYHA class as in our case. ${ }^{8}$

Echocardiogram shows that ARNI promotes a left ventricle reverse remodeling improving parietal kinetics both on the transverse plane and on the longitudinal axis, as detected by the GLS, ${ }^{10-12}$ but it seems to be a later finding even by the use of this tool which revealed high sensitivity. ${ }^{13}$

This case has several implications in clinical practice: 1) not all the patients are the same and, despite state of the art guidelines guarantee an invaluable tool, a difficult patient should prompt strict follow-up as in many

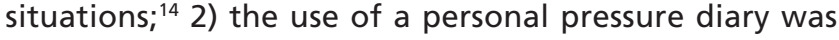
very helpful in reconstructing over time the clinical situation of the subject, showing that pressure stabilization (and so asthenia resolution) could require several days (in our case two weeks per step) despite diuretics reduction/suspension; 3) all the efforts and proper patient motivation should be done to avoid ARNI suspension; 4) ARNI therapy could offer electrical stabilization before a clear reverse remodeling could be documented by echocardiography even by a sensitive tool such as strain imaging; 5) current management and timing for offering ICD implantation, despite considerable technological improvement, ${ }^{15,16}$ could be reviewed in order to avoid ICD implantation, at least in a subset of young HF patients in primary prevention. In future large clinical trials could confirm this data.

\section{Conclusions}

Implementation of ARNI therapy in HFrEF has a high impact on clinical practice. While a potential reverse electrical remodeling effect should be demonstrated by specific large trials, its role could impact rapidly both on the clinical HF specialist and on the electrophysiologist. Perhaps a subset of patients could receive a benefit, during ARNI therapy, procrastinating further ICD implantation and accepting even for long-time symptoms related to hypotension. 


\section{Conflict of interest \\ None.}

\section{Funding body}

None.

\section{Ethical statement}

Authors state that the research was conducted according to ethical standard.

\section{Informed consent}

Informed consent was obtained from the patient.

\section{References}

1. Lee CS, Auld J. Crit Care. Heart Failure: A Primer. Nurs Clin North Am 2015;27:413-425.

2. Banerjee S, McCormack S. Ottawa (ON). Natriuretic Peptide Testing for Monitoring of Heart Failure Therapy: A Review of Clinical Effectiveness, Clinical Utility, Cost-Effectiveness, and Guidelines. Canadian Agency for Drugs and Technologies in Health; 2019 Aug.

3. Mosterd A, Hoes AW. Clinical epidemiology of heart failure. Heart 2007;93:1137-1146.

4. Moertl D. Disease management programs in heart failure: half a century of an unmet need. Wien Klin Wochenschr 2017;129:861-863.

5. Ponikowski P, Voors AA, Anker SD, et al. 2016 ESC Guidelines for the diagnosis and treatment of acute and chronic heart failure. Eur Heart J 2016;37:2129-2200.

6. Khder Y, Shi V, McMurray JJV, Lefkowitz MP. Sacubitril/ Valsartan (LCZ696) in Heart Failure. Handb Exp Pharmacol 2017;243:133-165.
7. McMurray JJV, Packer M, Desai AS, et al. AngiotensinNeprilysin Inhibition versus Enalapril in Heart Failure. N Engl J Med 2014;371:993-1004.

8. Ferreira JP, Metra M, Anker SD, et al. Clinical correlates and outcome associated with changes in 6-minute walking distance in patients with heart failure: findings from the BIOSTAT-CHF study. Eur J Heart Fail 2019;21:218-226.

9. Dattilo G, Borgia F, Guarneri C, et al. Cardiovascular Risk in Psoriasis: Current State of the Art. Curr Vasc Pharmacol 2019;17:85-91.

10. De Vecchis R, Paccone A, Di Maio M. Sacubitril/Valsartan Therapy for 14 Months Induces a Marked Improvement of Global Longitudinal Strain in Patients With Chronic Heart Failure: A Retrospective Cohort Study. Cardiol Res 2019;10:293302.

11. Dattilo G, Imbalzano E, Lamari A, et al. Ischemic heart disease and early diagnosis. Study on the predictive value of 2D strain. Int J Cardiol 2016;215:150-156.

12. Williams LK, Urbano-Moral JA, Rowin EJ, et al. Velocity vector imaging in the measurement of left ventricular myocardial mechanics on cardiac magnetic resonance imaging: correlations with echocardiographically derived strain values. J Am Soc Echocardiogr 2013;26:1153-1162.

13. de Gregorio C, Laterra G, Vaccaro V, et al. Time-based clinical and functional achievements in real-life HF patients on ARNI treatment. Eur J Intern Med 2020 Feb 20. doi: 10.1016/j. ejim.2020.02.007. [Epub ahead of print].

14. Dattilo G, Falanga G, Casale M et al. Oral Anticoagulants: Old and New Therapy. In: Berhardt LV (Ed.). Advances in Medicine and Biology. Volume 83. New York: Nova Science Publishers, Inc.; 2015:13-70.

15. Casale $\mathbf{M}$, et al. Cardiac implantable devices and takotsubo syndrome. A rare but potential eventuality. Cor Vasa 2018;60:e500-e502

16. Scarano M, Gizzi G, Mastrodicasa D, Mantini C. Cardiac implantable electronic devices and chemotherapy: A risky combination. Cor Vasa 2018;60:e469-e471. 